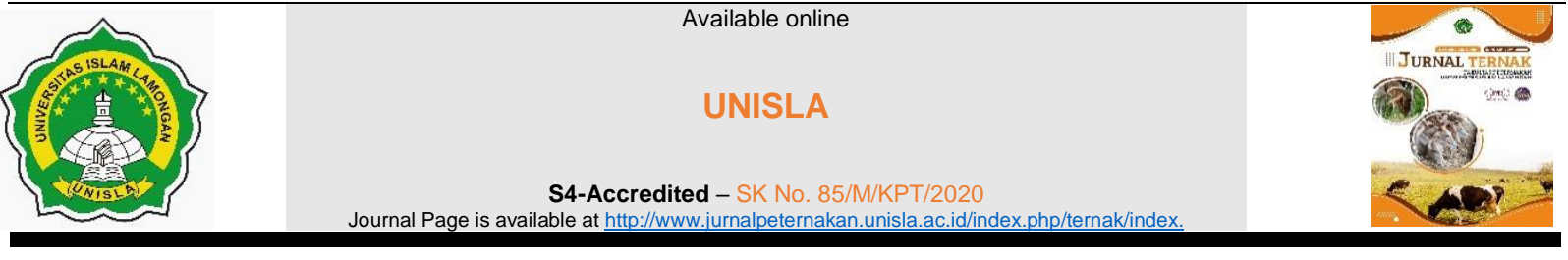

\title{
The Effect of Giving Maggot Mix Flour (Hermetia Illuciens Linnaeus) on Commercial Feed on Growth Weight Mice (Mus Musculus)
}

\author{
Dyanovita Al Kurnia a $a^{*}$, Arif Aria Hertanto ${ }^{b}$, Wardoyo $^{c}$, Nuril Badriyah ${ }^{d}$, Wahyuni ${ }^{e}$ \\ $a^{*} b, b, c, d, e$ Faculty of Animal Science, Universitas Islam Lamongan, East Java, Indonesia \\ email:"dyanovita@unisla.ac.id
}

\begin{tabular}{l}
\hline A R T I C L E I N F O \\
\hline Article history: \\
Received 14 December 2020 \\
Revised 28 February 2021 \\
Accepted 13 March 2021 \\
Available online 15 March \\
2021 \\
\hline
\end{tabular}

Keywords:

Body weight

Mice

Maggots

Feed

Growth

\section{IEEE style in citing this} article:

D.A. Kurnia, A. A. Hertanto and Wardoyo, N. Badriyah " The Effect of Giving Maggot Mix Flour (Hermetia Illuciens Linnaeus) on Commercial Feed on Growth Weight Mice (Mus Musculus, Jurnal Ternak Universitas Islam Lamongan, vol. 12, no. 1, pp. 6 - 10, 2021.

\section{A B S T R A C T}

The study aimed to determine the effect of daily body weight gain $(\mathrm{PBBH})$ in mice given feed containing commercial feed mix maggot flour. The material used in the study was 60 mice that were not differentiated by gender. The study used a completely randomized design (CRD) with unidirectional pattern. The provision of maggot flour in commercial feed was divided into four types of treatment. Each treatment level received three replications, with each replication consisting of 5 mice. If there was an influence on the treatment, the Duncan Multiple Range Test was performed. The followings were the treatments used in the study: P0: 100\% commercial feed without maggot flour, P1: commercial feed 95\% $+5 \%$ maggot flour, P2: commercial feed $90 \%+10 \%$ maggot flour, P3: commercial feed $85 \%+$ $15 \%$ maggot flour. The research lasted for approximately 30 days, starting from September 4 to October 6, 2020, at the Basic Laboratory of the Faculty of Animal Husbandry, Islamic University of Lamongan. The results showed a significant effect between treatments $(\mathrm{P}<0.05)$ and $(\mathrm{P}<0.01)$. The best treatment resulted in the increase of daily body weight gain $(\mathrm{PBBH})$ was $\mathrm{P} 1(0.35 \mathrm{gr} /$ head / day \pm 0.10$)$, P0 (0.29 gr / head / day \pm 0.05$),$ P3 (0.20 gr / head / day \pm 0.08$),$ P2 (0.10 gr / head / day \pm 0.05$)$. This study concludes that the application of mixed maggot flour as feed to the growth of mice's body weight is the addition of $95 \%$ of commercial feed and $5 \%$ of maggot flour.

Jurnal Ternak (Animal Science Journal) Faculty of Animal science - Lamongan Islamic University) with CC BY NC SA license.

\section{Introduction}

Mice (Mus musculus) are small mammals with high beneficial values. The increased benefits of mice, among others, are often used as experimental animals, including trying new feeds such as commercial feed mix maggot flour before a mixed feed is tested on other large livestock in the field of animal husbandry [1].

Maggot flour is the result of maggot siege. One of the feed ingredients that contain chitin is $9 \%$. [2]. Apart from chitin maggot, BSF also has higher linoleic fatty acids, approximately $0.70 \%$, based on [3]. [4] revealed that linoleic affects cholesterol concentration in eggs. According to [5] high protein maggots, as antimicrobial, have antibiofilm activity, anti-fungal, anti-inflammatory, and proangiogenic activity, immunomodulatory function, as a procoagulant, neurogenetic activity, anti-tumor activity, antiatherosclerosis activity, play a role in fibroblast migration. From the various procedures, maggot flour is predicted to improve mice's productivity by measuring the weight gain of mice [6].

Bodyweight gain is the change in body weight measurements measured over a certain period. Bodyweight gain (PBB) is one of the criteria used to measure growth [7]. Weight gain is correspondingly able to be used to assess the quality of animal feed ingredients. The weight gain obtained from 
experiments in livestock is the result of food substances consumed. From PBB data, the value of a food substance from an animal will be able to be known [8]. According to [9] a mouse's growth speed is 5 grams per day. [10] stated that the growth rate depends on the species, sex, age, and the balance of nutrients in the ration.

The factors influencing body weight gain are $45 \%$ internal factors and $55 \%$ external/environmental factors [11]. One of the environmental factors is the quality of feed. Environmental factors contribute an essential role in influencing body weight gain, especially the balance of energy and protein and other feed substances contained in the feed. One of the factors that influence mice's growth is the quality of feed for body metabolism [12].

\section{Method}

The method used in this study was a completely randomized design with four treatments. Each treatment used three replications. Each replications, five mice were used. The medicines used were as follows:

P0: $100 \%$ commercial feed without maggot flour.

P1: commercial feed $95 \%+5 \%$ maggot flour.

P2: commercial feed $90 \%+10 \%$ maggot flour.

P3: commercial feed $85 \%+15 \%$ maggot flour.

This study used 60 adult mice aged seven weeks with undifferentiated sex (unsex) maintained for 30 days.

The cage used was a unique iron cage for mice; the mice are kept in a cell measuring $50 \mathrm{~cm}$ long x $30 \mathrm{~cm}$ wide.

The feed used in this research was a commercial feed produced by PT X Tbk as a control feed. The treatment feed was commercial feed with maggot flour in $5 \%, 10 \%$, and $15 \%$ of the total ration. The need for adult mice was 16 grams/head/day.

Feeding was given twice a day, at 07.00 and $16.00 \mathrm{WIB}$, and drinking water was provided ad libitum, meaning that it was given continuously without limits.

Table 1. The nutritional content of research commercial feed

\begin{tabular}{|c|c|c|}
\hline No. & Food Substances & Percentage $(\%)$ \\
\hline 1 & Water content & 13 \\
\hline 2 & Protein & $20-22$ \\
\hline 3 & Fat & 3 \\
\hline 4 & Fiber & 5 \\
\hline 5 & Ash & 7 \\
\hline 6 & Calcium & 0.90 \\
\hline 7 & Phosphorous & 0.60 \\
\hline
\end{tabular}

Source: PT X, (2018)

Table 2. The nutritional content of research maggot flour

\begin{tabular}{clcc}
\hline No. & & Food Substances & Percentage $(\%)$ \\
\hline 1 & Water content & 6.66 \\
2 & Protein & 30.90 \\
3 & Fat & 40.83 \\
4 & Fiber & 9.98 \\
5 & Ash & 6.85 \\
6 & TDN & 50 \\
\hline
\end{tabular}

Source: Department of livestock and fisheries (2020) 
Table 3. Nutritional Needs of Mice

\begin{tabular}{clcc}
\hline No. & & Food Substances & Percentage $(\%)$ \\
\hline 1 & TDN & 55 \\
2 & Protein & $21-26$ \\
3 & Fat & $11-13$ \\
4 & Fiber & 5 \\
5 & Ash & $5-6$ \\
\hline
\end{tabular}

Source: Noriko, et al. (2015)

Table 4. The nutritional content of treatment feed

\begin{tabular}{ccc}
\hline Treatment & Food Substances & Percentage (\%) \\
\hline P0 & TDN & 60 \\
& Protein & $21-26$ \\
& Fat & 3 \\
& Fiber & 5 \\
& Ash & 7 \\
P1 & TDN & 59.5 \\
& Protein & 21 \\
& Fat & 5.00 \\
& Fiber & 5.24 \\
P2 & Ash & 6 \\
& TDN & 56 \\
& Protein & 20 \\
& Fat & 6.8 \\
& Fiber & 5.27 \\
P3 & Ash & 6.67 \\
& TDN & 51.85 \\
& Protein & 19 \\
& Fat & 8.67 \\
& Fiber & 5.13 \\
& Ash & 6.11 \\
\hline
\end{tabular}

Source: Primary data processed

One of the observed changes was the increase in daily body weight (PBBH). The body weight gain $(\mathrm{g} / \mathrm{head})$ was obtained by calculating the difference every week between the mice's body weight and the importance of the initial mice.

Making maggot flour began with selecting a maggot ready to harvest or is 20 to 25 days old because the maggot was an adult [13]. Maggot was cleaned. Then the maggot was in the oven with a maximum temperature of $60^{\circ} \mathrm{C}$. The range's duration as marked by a color change in the maggot, a brownish color and an odor like shrimp paste. Afterwards, the maggot was grounded using a flour machine. The maggot should be completely dry and not greasy. Furthermore, mix maggot flour with finished feed according to the percentage level of treatment [14].

\section{Results and Discussion}

Research data of the application of Maggot Mix Flour (Hermetia Illuciens Linnaeus) in Commercial Feed to the Growth of Mice (Mus Musculus) can be seen in table 5 . 
Table 5. Research Results Application of Maggot Mix Flour (Hermetia Illuciens Linnaeus) in Commercial Feed to the Growth of Mice (Mus Musculus)

\begin{tabular}{cc}
\hline & Measured Variables \\
\cline { 2 - 2 } Treatment & PBB $(\mathrm{gr} / \mathrm{hr})$ \\
\hline P0 & $0.29 \pm 0.05 \mathrm{bc}$ \\
P1 & $0.35 \pm 0.10 \mathrm{c}$ \\
P2 & $0.10 \pm 0.03 \mathrm{a}$ \\
P3 & $0.20 \pm 0.08 \mathrm{ab}$ \\
\hline
\end{tabular}

Note: Different superscripts (ac) in the same column and form showed exceedingly significant different effects $(\mathrm{P}<0.01)$.

The average body weight gain based on Table 5 showed that there was an effect of treatment on body weight growth, where P1 achieved the highest body weight growth with the addition of maggot mix flour commercial feed level of $5 \%(0.35 \mathrm{gr} / \mathrm{head} /$ day \pm 0.10$)$, while the lowest was in P2 $(0.10 \pm 0.03)$. Statistical analysis was carried out to determine the effect of treatment on the body weight gain of mice [9].

The results of statistical analysis showed that the application of Maggot Mix Flour (Hermetia Illuciens Linnaeus) to Commercial Feed on the Growth of Body Weight of Mice (Mus Musculus) had a exceedingly significant effect on the growth of body weight of mice $(\mathrm{P}<0.01)$. It was because maggot flour's nutritional content was added to feed that had good nutritional content, as shown in table 4. [15]. That digestive enzyme activity, in general, can be influenced by other factors, including genetics, feed composition, and intake.

\section{Conclusions}

The application of mixed maggot flour as feed to the growth of mice's body weight is the addition of $95 \%$ of commercial feed and $5 \%$ of maggot flour.

\section{References}

[1] S. Sulastri, M. D. Iqbal Hamdani, and A. Dakhlan, "Buku Ajar Dasar Pemuliaan Ternak." AURA, CV. Anugrah Utama Raharja, 2019.

[2] M. Meneguz, L. Gasco, and J. K. Tomberlin, "Impact of pH and feeding system on black soldier fly (Hermetia illucens, L; Diptera: Stratiomyidae) larval development," PLoS One, vol. 13, no. 8, p. e0202591, 2018.

[3] A. Dörper, T. Veldkamp, and M. Dicke, "Use of black soldier fly and house fly in feed to promote sustainable poultry production," J. Insects as Food Feed, pp. 1-20, 2020.

[4] S. Diener, C. Zurbrügg, and K. Tockner, "Conversion of organic material by black soldier fly larvae: establishing optimal feeding rates," Waste Manag. Res., vol. 27, no. 6, pp. 603-610, 2009.

[5] S. Diener, N. M. S. Solano, F. R. Gutiérrez, C. Zurbrügg, and K. Tockner, “Biological treatment of municipal organic waste using black soldier fly larvae," Waste and Biomass Valorization, vol. 2, no. 4, pp. 357-363, 2011.

[6] A. El-Hack et al., "Black Soldier Fly (Hermetia illucens) Meal as a Promising Feed Ingredient for Poultry: A Comprehensive Review," Agriculture, vol. 10, no. 8, p. 339, 2020.

[7] Y.-S. Wang and M. Shelomi, "Review of black soldier fly (Hermetia illucens) as animal feed and human food," Foods, vol. 6, no. 10, p. 91, 2017.

[8] D. S. Aditya, "Organ Reproduksi Dan Kualitas Sperma Mencit (Mus Musculus) Yang

Mendapat Pakan Tambahan Kemangi (Ocimum Basilicum) Segar," Progr. Stud. Teknol. Produksi Ternak Fak. Peternak. Inst. Pertan. Bogor, 2006.

[9] I. Swinscoe, D. M. Oliver, R. Ørnsrud, and R. S. Quilliam, "The microbial safety of seaweed as 
a feed component for black soldier fly (Hermetia illucens) larvae," Food Microbiol., vol. 91, p. 103535, 2020.

[10] O. Shishkov, M. Hu, C. Johnson, and D. L. Hu, "Black soldier fly larvae feed by forming a fountain around food," J. R. Soc. Interface, vol. 16, no. 151, p. 20180735, 2019.

[11] S. Hidayati, E. Kurnianto, and S. Johari, "Analisis ragam dan peragam bobot badan kambing peranakan Ettawa," J. Vet., vol. 16, no. 1, pp. 107-116, 2015.

[12] K. B. Barragan-Fonseca, M. Dicke, and J. J. A. van Loon, "Nutritional value of the black soldier fly (Hermetia illucens L.) and its suitability as animal feed-a review," J. Insects as Food Feed, vol. 3, no. 2, pp. 105-120, 2017.

[13] E. M. Nyakeri, M. A. Ayieko, F. A. Amimo, H. Salum, and H. J. O. Ogola, "An optimal feeding strategy for black soldier fly larvae biomass production and faecal sludge reduction," J. Insects as Food Feed, vol. 5, no. 3, pp. 201-213, 2019.

[14] C. Truzzi et al., "Fatty acids profile of black soldier fly (Hermetia illucens): Influence of feeding substrate based on coffee-waste silverskin enriched with microalgae," Anim. Feed Sci. Technol., vol. 259, p. 114309, 2020.

[15] M. Cullere et al., "Black soldier fly as dietary protein source for broiler quails: apparent digestibility, excreta microbial load, feed choice, performance, carcass and meat traits," Animal, vol. 10, no. 12, pp. 1923-1930, 2016. 